\title{
Folklore in Meme: Minangkabau Folklore Survival Form in The Digital World
}

\author{
H N Hidayat ${ }^{1}$, Wasana ${ }^{2}$, Pramono ${ }^{3}$, T Immerry ${ }^{4}$, F Dahlan ${ }^{5}$ \\ $\left\{{ }^{1}\right.$ herrynh@hum.unand.ac.id, ${ }^{2}$ wasana@hum.unand.ac.id, ${ }^{3}$ pramono@hum.unand.ac.id, \\ 4immerry20@bunghatta.ac.id, ${ }^{5}$ femmydahlan@bunghatta.ac.id \} \\ ${ }^{1,2,3}$ Universitas Andalas Padang, Indonesia \\ ${ }^{4,5}$ Universitas Bung Hatta Padang, Indonesia
}

\begin{abstract}
A meme has become a communication trend in social media. Although it tends to contain humor, memes have become the identity of a community group. Many memes in Minangkabau language contain folklore. As one form of a cultural symbol, it is a possibility that memes are a transformation of the previous culture. This article presents the survival of the Minangkabau folklore in the digital era, which are in memes form. The object of this study is the Minangkabau language memes on Instagram. Search and collection results are then grouped according to their visual form and contents. The analysis shows that there is still a folklore content in many Minangkabau memes, including rhymes, proverbs, pepatah petitih, myths, legends, and people's beliefs. In general, the content of folklore in memes is conveyed through satire which sometimes tends to be sarcastic. Indirectly this also shows that netizens as folk are a significant element in the development of the Minangkabau folklore.
\end{abstract}

Keywords: Folklore, Minangkabau, Digital, Internet, Meme

\section{INTRODUCTION}

Although known in a non-verbal form, folklore also is known as a product of oral tradition. The spread method and the orality seemed to be a standard and category of distinctiveness of folklore. But in the last two decades, discussions and research on folklore have shifted because the media changed.

Today, folklore's documentation and archiving activities have shifted to digital-based activities. Data collectors and researchers compete to share knowledge and the wealth of their respective traditions. Mapping study and folklore objects are no longer limited to local areas but in regional and even global regions. The process and results of digitalization of folklore directly added new areas of study for folklorist. Today's folklore study has penetrated into "computational folkloristics" [1].

For folklorist, folklore reflects the values of a social community. As a cultural symbol, folklore reflects a habit that expands into a tradition of society. On the other hand, the advancement of information technology made a shift towards the theoretical understanding of folklore. The issue of folklore contained in digital communication has become the current trend. Folklorist no longer only dwells on legends, myths, customs, and superstition, but switches to digital-based communication and the internet. Folklore has changed and developed into efolklore (internet-based folklore) and newslore (news-based folklore). However, the 
peculiarities of folk and lore as the main components of folklore did not change because of the media changing.

Netizens as folk and their values as lore remain as important elements in e-folklore [2]. The internet folklore includes folklore about the internet, folklore on the internet, and folklore on the internet related to real life [3]. New characteristics of this technology-based folklore is that repetition and its variations are temporary and fade within a certain period. Blank [4] mentions that this characteristic makes it difficult for folklorist to discover the origin of this digital folklore culture while at the same time demonstrating the importance of this studies.

However, the task of a folklorist is not to find truth in folklore, but to find out how folklore as an expression is considered true by a society. Gencarella [5] states that a critical study of folklore must show folklore as an articulation of expectation, not the core.

Here shows the correlation between the formation of a society and the formation of its products as a representation of themselves. Changes and advancements in the mindset and knowledge of society will also affect its folklore, both in form and media. Roth [6] states that the transformation of folklore is a form of communication between humans and culture.

In this state, folklore transformations can have various forms. In general, this transformation is through genres and media. The well-known forms of this transformation are comics, films, animations, and even games [7]. In cyberspace, folklore can transform as memes [8]-[11] and studies of them are need because memes can be assigned as a social communication system. Domokos [12] states contemporary folklore studies can make a relevant contribution to the understanding of the changed communicational situation in the $21^{\text {st }}$ century.

\section{RESEARCH METHOD}

Meme was described by Richard Dawkins in his book The Selfish Gene as "a unit of cultural transmission or a unit of imitation". The term, meme suggestive of " $\mathrm{m}$ " for memory or imitation and "eme" for gene. In this biological term, Dawkins suggested that all life in the universe must evolve by the differential survival of slightly inaccurate self-replicating entities; he called these "replicators". Furthermore, these replicators automatically band together into groups to create systems that carry them around and operate to favors their continued replication. Because of its nature; imitate and replicate; meme becomes study material not only in the biological field but social science also as Dawkins [13] also state the term 'meme' for a social replicator, the examples he uses being tunes or jokes. A 'successful' replicator in this context is a tune or joke which can 'get itself' transmitted continuously. An 'unsuccessful' one is not passed on and is forgotten. These ideas also arise in a number of other contexts.

In this paper, meme refers to a message that propagate, persist, and has an impact [14]. Besides that, meme is a symbol that requires no explanation, and which can be taken the form of words, actions, sounds, drawings, conveying an idea.

The first memes that appeared on the internet were graphic, often schematic images of men called "emotional piki" who expressed a certain emotion or character, and from which were built amateur short comics with a simple plot. The most used "memopics" have become a unified and widespread means of communication, forging on the internet network, for the help of which they expressed their own emotions (such as emoticons), creation cutting off various comic stories [11].

There are various memes with folklore contents on the internet, mainly on Instagram. In the qualitative method framework, this paper presents meme samples with Minangkabau folklore. That meme was collected from several Instagram accounts with a Minangkabau hashtag \#minangkabau. Before being analyzed, the memes did classify according to the kind of folklore. 
Analysis and interpretation continued not only to the folklores kind but also the meme form as a representation of folklore's survival against the digital era.

\section{RESULT AND DISCUSSION}

If compared, folklore and meme have equated characteristics. Both are spread, propagate and bring information on a certain community. It is possible if memes contain folklore and even memes are folklore itself. It shows creativity in folklore transformation to digital media. They bring both two aspects, text and image, which are not exist on traditional folklore.

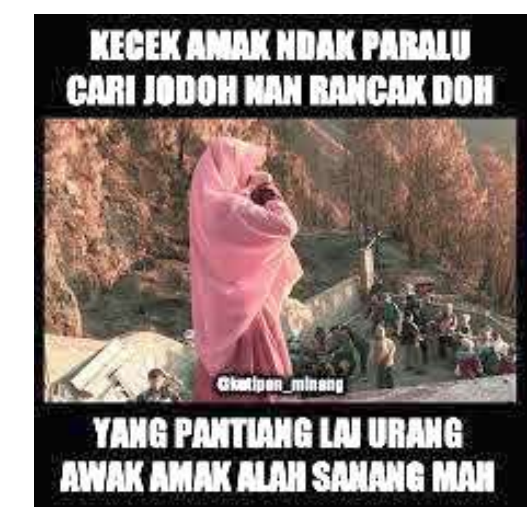

Figure 1. Mother's wish for her child's mate

The description above is implicitly carried in the text (Figure 1). Kecek amak ndak paralu cari jodoh nan rancak doh, mother doesn't look for a beautiful/handsome mate, implying the Minangkabau's openness to marriage. The physical appearance and origin of future brides is not a concern for Minangkabaunesse. However, the sentence was continued, yang pantiang lai urang awak amak alah sanang mah the important thing was that he/she is urang awak (Minangkabau) mother quite happy. The sentence implies the parents' tendency who prefer the mate to their fellow Minangkabaunesse (ideal marriage for Minangkabaunesse).

As one of the ethnic with a communal family system, Minangkabau has two types or forms of marriage that are ideal marriage and abstinence marriage [15]. Ideal marriage for Minangkabaunesse is prioritizing intermarriages which are termed of awak samo awak and personified with kuah tatuang ka nasi (soup poured on rice) or pulang ka bako (back to father's relatives) [16]-[18]. However, the Minangkabaunesse are also open to interethnic marriages by enrolling future daughter/son-in-law to kaum induak bako (father's relatives) as kemanakan nan mancari induak (nephew/niece) [19]. It shows that marriage in Minangkabau today is merely an agreement. The practice also illustrates the Minangkabaunesse intelligence in overcoming the pressure of adat and tradition to accommodate their interests and hopes in facing life. This effort and strategy are called the politics of marriage [20]. 


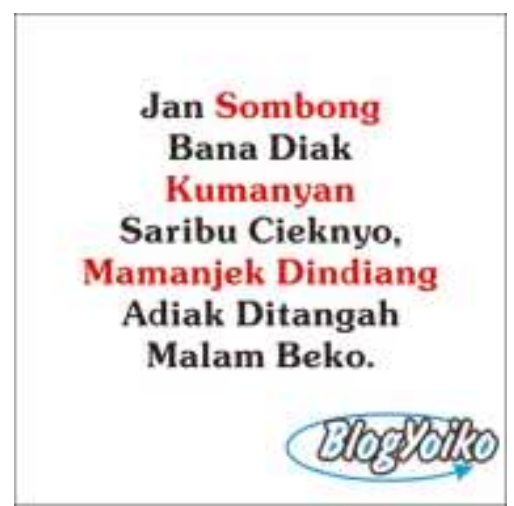

Figure 2. Sorcery in meme

Superstitions and myths are committed as folklore [21]. In terms of the use of spells and inheritance shamanism can also be categorized as folklore. Shaman, magic, and spell, as anthropologists and folklorist deal with it, relate to a world of action both benevolent and malevolent by powers and beings that may be variously human, nonhuman, natural and supernatural.

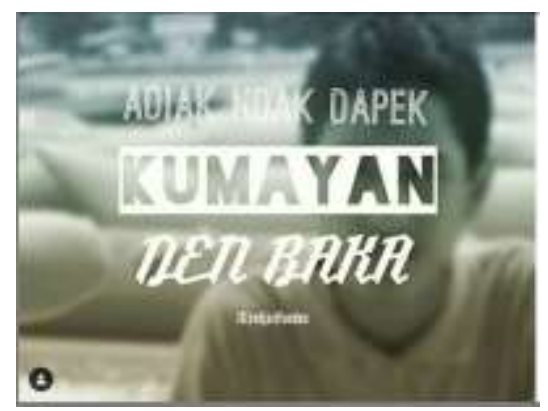

Figure 3. More sorcery in meme

Figure 2 and figure 3 indirectly shows the beliefs of the Minangkabaunesse towards shamanic practices. The sentence, jan sombong bana diak kumanyan saribu ciek nyo, mamanjek dindiang adiak di tangah malam beko (do not be arrogant, incense price only one thousand, you will climb the wall tonight) describing the anger of the young man because of the girl pride and threatening to bewitch the girl. The same tend also describe on adiak ndak dapek, kumayan den baka (if I can't get you, I'll burn the incense).

There is various sorcery in Minangkabau. The famous one is gasiang tangkurak. In practice, gasiang tangkurang uses mantra (spell) as media. This mantra can be categorized as mantra pelet. Wijaya [22] states pelet is a mystical thing and are used for them to achieve certain goals through shortcuts without effort and hard work. The methods also vary, some of which make the intermediary or supporting media as objects later used as an amulet, charm, or protection. As a tool, Putra [23] mentions gasiang tangkurak is a type of oval-shaped instrument (top spinning) with basic material from the forehead bones of a deceased person. This tool is required in the basirompak ritual which is a magical ritual to conquer a woman because she reject a man's love [24]. In addition, Elia [25] indicated to this activity as sijundai which in its mantra there are ideas which relate to the victim name (the girl), place, time indication, and the main action 
of sijundai to hurt the victim. Elia also added a pronoun that is often used for the victim is diak or adiak (Figure 2 and 3).

The Minangkabaunesse believes that this ritual still exists. This ritual is usually used for revenge. This sorcery victim will lose memories and doing crazy. Climbing the wall is the most popular victim actions [26]. Also, those two memes (Figure 2 and 3) illustrate one way to get a lover through the practice of black magic which can be seen from the text incense (kumanyan, kumayan). Kemenyan has been commonly regarded as one of the means in offerings or worship [27]. Therefore, incense as a tool contains connotations as inviters of spirits or spirits [28] in the world of shamanism [29]. According to Asaari [30], incense is considered as a means of connecting the unseen world with the real world.

It shows that magic in folklore speaks of what "we" (moderns) have never known, or left behind. It is a myth of lost spaces, fictive spaces. So, while we may never have lived/believed in a magical world, contemplation of the 'fantastic' domains of the magical is nonetheless a useful way of learning something about what we are, and what we are not. Moreover, it turns out that we are really not so far removed from the 'magical' sensibility of a transformation of the world through the word. [31].

This expanded view of folk culture, along with its more classic concerns, entails a variety of disciplinary and methodological emphases. Symbols that give shape to cultural worlds, and myths that convey bundles of knowledge that are absorbed by members of a society, are continually reconnected to the reality within which participants in a given society function. Rituals not only "reflect" society, but constitute a powerful transformative mechanism that makes and remakes these linkages. It is therefore necessary to examine these concepts at the level of performance as well as within the planes of meaning and significance [32].

\section{CONCLUSIONS}

Folklore has exceeded space and time. The folklore transformation - form, variety, and type - in the digital world and internet is documentation of folklore's survival. Meme as a folklore's transformation has shown netizens as folk who remain loyal to their tradition or lore. The correlative relationship between folk and lore will continue to change and develop along with the advancement of technology and human knowledge.

\section{ACKNOWLEDGEMENTS}

The author expresses gratitude to Fakultas Ilmu Budaya Universitas Andalas, Lembaga Penelitian dan Pengabdian kepada Masyarakat (LPPM) Universitas Andalas, Program Studi Sastra Minangkabau Universitas Andalas, and Asosiasi Dosen Pendidikan Bahasa Indonesia (ADOBSI).

\section{REFERENCES}

[1] T. R. Tangherlini, "Big Folklore : A Special Issue on Computational Folkloristics," J. Am. Folk., vol. 129, no. 511, pp. 5-13, 2016.

[2] V. Krawczyk-Wasilewska, "e-Folklore in the Age of Globalization," Fabula, vol. 47, no. 3/4, p. 248, 2006.

[3] T. J. Blank, Ed., Folk Culture in the Digital Age: The Emergent Dynamics of Human Interaction. Boulder: Utah State University Press, 2012.

[4] T. J. Blank, "Folklore and the Internet: The Challenge of an Ephemeral Landscape," 
Humanities, vol. 7, no. 2, p. 50, 2018.

[5] S. O. Gencarella, "Constituting Folklore : A Case for Critical Folklore Studies," J. Am. Folk., vol. 122, no. 484, pp. 172-196, 2009.

[6] K. Roth, "Crossing Boundaries: the Translation and Cultural Adaptation of Folk Narratives," Fabula, vol. 39, no. 33/34, pp. 243-255, 1998.

[7] H. N. Hidayat and Wasana, "Melampaui Kata: Transformasi Folklore," in Khazanah Melayu Serumpun dalam Era Baharu, 2018, pp. 306-313.

[8] G. de Seta, "Digital Folklore," in Second International Handbook of Internet Research, Dordrecht: Springer Netherlands, 2019, pp. 1-17.

[9] H. E. Huntington, "Subversive Memes: Internet Memes as a Form of Visual Rhetoric," AoIR Sel. Pap. Internet Res., vol. 14, 2013.

[10] E. Oring, "Memetics and Folkloristics: The Applications," West. Folk., vol. 4, no. 73, pp. 432-454, 2014.

[11] Z. Denysyuk, "Internet memes as a means of post-folklore communication," Natl. Acad. Manag. Staff Cult. Arts Her., vol. 0, no. 2, 2017.

[12] M. Domokos, "Folklore and Mobile Communication," Fabula, vol. 48, no. 1/2, pp. 5059, 2007.

[13] E. Chattoe, "VIRTUAL URBAN LEGENDS: INVESTIGATING THE ECOLOGY OF THE WORLD WIDE WEB," in A Memetic Compendium, R. Finkelstein, Ed. Maryland: Robotic Technology Inc, 2008.

[14] R. Finkelstein, Ed., A MEMETICS COMPENDIUM. Maryland: Robotic Technology Inc, 2008.

[15] A. Asmaniar, "PERKAWINAN ADAT MINANGKABAU," BINAMULIA Huk., vol. 7, no. 2, pp. 131-140, 2018.

[16] Y. Asri, "REFLEKSI IDEOLOGI WANITA MINANGKABAU DALAM NOVEL NEGERI PEREMPUAN KARYA WISRAN HADI," Humaniora, vol. 25, no. 1, pp. 69-81, 2013.

[17] R. Zakia, "KESETARAAN DAN KEADILAN GENDER DALAM ADAT MINANGKABAU," Kafa `ah J. Gend. Stud., vol. 1, no. 1, p. 39, Jan. 2011.

[18] D. N. Inda, "MEMANG JODOH: PEMBERONTAKAN MARAH RUSLI TERHADAP TRADISI MINANGKABAU," Kandai, vol. 11, no. 2, pp. 217-233, Jun. 2017.

[19] M. Abidin, "MINANGKABAU DAN SISTIM KEKERABATAN Hubungan Kekeluargaan Minangkabau, bersuku ke ibu, bersako ke mamak, dan bernasab ke ayah." 2012.

[20] Z. Arifin, "DUALITAS PRAKTIK PERKAWINAN MINANGKABAU," J. Hum., vol. 21, no. 2, pp. 150-161, Aug. 2012.

[21] J. Danandjaja, Folklor Indonesia: Ilmu Gosip, Dongeng, dan Lain Lain. Jakarta: Pustaka Grafitipress, 2002.

[22] H. Wijaya, "Bentuk dan Fungsi Mantra Pelet Dalam Masyarakat Sasak Di Desa Bagik Payung (Kajian Pisikologis)," in International Conference on Elementary and Teacher Education (ICETE), 2016.

[23] R. W. Putra, “ANIMISME DALAM KESENIAN SALUANG SIROMPAK,” Garak Jo Garik J. Pengkaj. dan Pencipta. Seni, vol. 12, no. 2, Nov. 2017.

[24] I. Teguh, "Gasing Tengkorak, Guna-guna dalam Tradisi Lisan Minangkabau - Tirto.ID," 2018. [Online]. Available: https://tirto.id/gasing-tengkorak-guna-guna-dalam-tradisilisan-minangkabau-dcNf. [Accessed: 20-Apr-2019].

[25] F. Elia and I. T. Abdullah, "Sirompak, Satu Ragam Mantra dalam Tradisi Lisan 
Minangkabau," Humanika, vol. 17, no. 2, 2004.

[26] Rang Paniang, "GASIANG TANGKURAK DAN SIJUNDAI," 2011. [Online]. Available: $\quad$ http://buyuang87.blogspot.com/2011/01/gasiang-tangkurak-dansijundai.html.

[27] T. Wahyudi, R. Rafiloza, and E. Ediwar, "Ritual Basirompak Memiliki Unsur Musikal di Nagari Taeh Baruah Kab. Limopuluah Kota Payokumbuah,” Besaung J. Seni, Desain dan Budaya, vol. 4, no. 2, Mar. 2019.

[28] M. Nofrita and H. Hermawan, "TRADISI LUKAH GILO MASYARAKAT BONAI KABUPATEN ROKAN HULU: PEMBELAJARAN ANALISIS SEMIOTIKA,” $J$. Pendidik. ROKANIA, vol. 3, no. 3, pp. 357-365, Dec. 2018.

[29] A. N. Musadad, "PERSINGGUNGAN ISLAM DAN TRADISI MISTIK LOKAL: STUDI KASUS PANANYAAN DAN AHLI HIKMAH DI MASYARAKAT TASIKMALAYA," Indones. J. Islam. Lit. Muslim Soc., vol. 1, no. 1, 2016.

[30] A. Asaari, J. Azis, and S. M. Salleh, "Susuk, Wanita Dan Abjection Dalam Filem Seram Kontemporari Melayu," J. Komun. Malaysian J. Commun., vol. 33, no. 3, Sep. 2017.

[31] M. O'Connor, "THE PASSAGE FROM MAGIC TO FOLKLORE Death, Magic and Mana Maori in Aotearoa/New Zealand," in The Colloque International: 'Magie et Fantastique dans le Pacifique,', 1993.

[32] H. Salamon and H. E. Goldberg, "MYTH-RITUAL-SYMBOL," in A Companion to Folklore, West Sussex: Blackwell Publishing, 2012. 